\title{
DO ACESSO AO JUDICIÁRIO AO ACESSO À JUSTIÇA: CAMINHOS PARA A SUPERAÇÃO DA CULTURA DO LITÍGIO PROCESSUAL POR VIAS AUTOCOMPOSITIVAS E EXTRAJUDICIAIS ${ }^{1}$
}

\section{FROM ACCESS TO THE JUDICIARY TO ACCESS TO JUSTICE: WAYS TO OVERCOME THE CULTURE OF PROCEDURAL LITIGATION THROUGH SELF-COMPOSITION AND EXTRAJUDICIAL WAYS}

Nilsiton Rodrigues de Andrade Aragão Doutorado e mestrado em Direito Constitucional pela Universidade de Fortaleza. Especialização e Graduação em Direito pelo Centro Universitário Professor universitário da graduação na Universidade de Fortaleza e da pós-graduação em diversas Instituições de Ensino Superior. Membro da Associação Norte Nordeste de Professores de Processo ANNEP e do Instituto Brasileiro de Direito Processual IBDP. Superintende da Área Judiciária do Tribunal de Justiça do Estado do Ceará. Conciliador e Mediador Judicial credenciado junto ao CNJ. Instrutor em Mediação e Conciliação Judiciais. Fortaleza/CE. E-mail: nilsiton_aragao@hotmail.com

RESUMO: O objetivo principal deste trabalho é analisar como as formas heterocompositivas e autocompositivas de resolução de conflitos realizadas tanto no âmbito judicial quanto extrajudicial contribuem para o efetivo acesso à justiça. $\mathrm{O}$ tema escolhido justifica-se por ser necessário compreender a baixa adesão que das vias autocompositivas e extrajudiciais. A pesquisa centra-se na coleta de dados bibliográficos e documentais e na análise da legislação. Constatou-se uma tendência de concentração da solução dos conflitos no âmbito judicial e uma resistência as vias

\footnotetext{
${ }^{1}$ Artigo recebido em 02/10/2021 e aprovado em 16/11/2021.
} 
autocompositivas e extrajudiciais, o que restringe um importante campo para o desenvolvimento do acesso à Justiça.

PALAVRAS-CHAVE: Acesso à justiça; justiça multiportas; mediação extrajudicial; Código de Processo Civil.

\begin{abstract}
The main objective of this work is to analyze how the heterocompositional and self-compositional forms of conflict resolution carried out both in the judicial and extrajudicial scope contribute to the effective access to justice. The chosen theme is justified because it is necessary to understand the low adherence that the autocomposition and extrajudicial ways. The research focuses on the collection of bibliographic and documental data and on the analysis of legislation. There was a tendency to concentrate conflict resolution in the judicial sphere and a resistance to selfcomposition and extrajudicial ways, which restricts an important field for the development of access to justice.
\end{abstract}

KEYWORDS: Access to justice; multi-port justice; extrajudicial mediation; Code of Civil Procedure.

\title{
1. INTRODUÇÃO
}

O objetivo principal deste trabalho é analisar como as formas heterocompositivas e autocompositivas de resolução de conflitos, realizadas tanto no âmbito judicial quanto extrajudicial, contribuem para o efetivo acesso à Justiça.

No Brasil há uma tendência de judicialização de conflitos em busca de uma solução substitutiva da vontade das partes. A via judicial adjudicatória se apresenta como caminho quase exclusivo de solução de conflitos, sendo este um dos fatores que colaboram para a dificuldade de entrega de uma prestação jurisdicional justa, célere e efetiva. Nesse contexto, verifica-se um ambiente pouco fecundo para o desenvolvimento e adesão efetiva a outras formas de solução de conflitos. Políticas públicas, projetos e 
ações tendentes a promover mudanças se deparam com dificuldades profundas e estruturais que colaboram para a manutenção de um círculo vicioso.

Sob essas considerações introdutórias questiona-se: qual a origem da cultura do litígio processual? É possível desenvolver outras formas de acesso à justiça sem violar a inafastabilidade da jurisdição? Como as vias judiciais e extrajudiciais de solução consensual de conflitos podem coexistir e interagir? Dentre outras, são estas reflexões que merecem ser analisadas, tendo em vista as consequências práticas que se apresentam.

A primeira parte do estudo será destinada a realização de um diagnóstico da situação atual. Para tentar construir caminhos de superação da cultura do litígio processual é preciso primeiro compreender sua origem e seus fundamentos. Para isso, serão analisadas inicialmente a universalização do acesso ao Judiciário e da posição histórica de preponderância do Poder Judiciário na solução dos conflitos.

Os capítulos finais serão dedicados à verificação da insuficiência da solução de conflitos pela via adjudicatória da sentença judicial. Será abordada a posição dos meios autocompositivos de gestão do conflito no acesso à justiça, examinando-se se esses métodos são compatíveis com um sistema judicial que disponibilize tais vias de forma cumulada para melhor comportar as especificidades de cada conflito.

\section{DA UNIVERSALIZAÇÃO DO ACESSO AO JUDICIÁRIO À CULTURA DE JUDICIALIZAÇÃO DE CONFLITOS}

A inafastabilidade da jurisdição prevista no artigo $5^{\circ}, \mathrm{XXXV}$, da Constituição Federal (CF) de 1988 é textualmente uma norma limitativa direcionada aos Poderes Executivo e Legislativo, demonstrando uma finalidade imediata de proibir a criação de obstáculos à propositura de demandas judiciais. No entanto, o fundamento axiológico dessa garantia fundamental volta-se indubitavelmente para os próprios jurisdicionados, como forma de resguardar-lhes o acesso à justiça.

O direito ao acesso à justiça apresenta-se como peça-base de um Estado Democrático de Direito, pois se realiza, para além da propositura da demanda, com a imposição de se efetivarem os efeitos práticos da prestação jurisdicional conduzida no 
processo, viabilizando o acesso a outros direitos. ${ }^{2}$ É, assim, uma garantia substantiva, possuindo núcleo valorativo próprio a ser assegurado, e, concomitantemente, uma garantia instrumental, que serve aos demais direitos ameaçados ou violados.

Além dessa bipartição significativa inicial, o conteúdo do acesso à justiça tem outras dimensões. Na linha das “ondas renovatórias de direito processual”, propostas por Cappelletti e Garth (1988), trabalho que se propôs a diagnosticar as causas da ineficiência da justiça, é possível dividir a evolução do direito ao acesso à justiça em, pelo menos, três dimensões bem definidas. A primeira é marcada pela defesa do acesso ao Poder Judiciário, a segunda, qualificada por ações tendentes a resguardar os interesses coletivos e difusos e a terceira, ligada à ideia de efetividade da tutela jurisdicional. Essa última exige, entre outros aspectos, uma resposta em prazo razoável, a instituição de procedimentos racionalizados e, o que mais importa para este trabalho, a promoção de uma solução efetiva para o litígio. ${ }^{3}$

Em uma análise da efetivação de cada uma dessas perspectivas do acesso à justiça no âmbito nacional, é possível observar uma evolução razoável, embora distante da plenitude, quanto à capacidade de submeter um litígio ao exame do Judiciário. Porém, no que concerne às outras dimensões, ainda se verifica um cenário mais grave de inefetividade. Essa disparidade de desenvolvimento das manifestações do acesso à justiça gera distorções entre a demanda, a resposta e a satisfação com a prestação jurisdicional.

O alargamento da porta de acesso à jurisdição é a política de mais fácil execução, mas insuficiente, se não estiver acompanhada de uma evolução equiparada das outras vertentes do acesso à justiça. É certo que a universalização do acesso ao

\footnotetext{
${ }^{2}$ Adverte Boaventura de Sousa Santos: "a consagração constitucional dos novos direitos econômicos e sociais e a sua expansão paralela à do Estado-Providência transformou o direito ao acesso efetivo à justiça num direito de charneira, um direito cuja denegação acarretaria a de todos os demais. Uma vez destituídos de mecanismo que fizessem impor o seu respeito, os novos direitos sociais e econômicos passariam a meras declarações políticas, de conteúdo e funções mistificadores". (SANTOS, Boaventura de Sousa. Pela mão de Alice: o social e o político na pós modernidade. 9. ed. São Paulo: Cortez, 2003, p. 167).

${ }^{3}$ Definem Mauro Cappelletti e Bryant Garth: "A expressão acesso à justiça é reconhecidamente de difícil definição, mas serve para determinar duas finalidades básicas do sistema jurídico - o sistema pelo qual as pessoas podem reivindicar seus direitos e/ou resolver seus litígios sob os auspícios do Estado. Primeiro, o sistema deve ser igualmente acessível a todos; segundo ele deve produzir resultados que sejam individual e socialmente justos". (CAPPELLETTI, Mauro; GARTH, Bryant. Acesso à justiça. Tradução de Ellen Gracie Northfleet. Porto Alegre: Sergio Antonio Fabris, 1988, p. 8).
} 
Judiciário é uma das dimensões mais relevantes desse direito. Ela assegura isonomia na busca por uma prestação jurisdicional, evitando que o Poder Judiciário seja ambiente reservado a indivíduos privilegiados, excluindo classes sociais menos favorecidas, com dificuldade de representação ou minorias.

Por outro lado, a compreensão exacerbada dessa abertura ao acesso à jurisdição é um dos fatores propulsores do ímpeto de judicialização de toda e qualquer espécie de conflito, por menor que seja a probabilidade de êxito ou por mais eficientes que se apresentem outras instâncias de enfrentamento. Essa visão, em alguns pontos, distorcida da universalidade da prestação jurisdicional e do direito ao acesso à justiça criou um cenário convidativo à propositura de ações judiciais, um dos fatores responsáveis pela elevação dos índices de litigiosidade no Brasil. ${ }^{4}$ Por essa razão, não se podem flexibilizar em absoluto as condições mínimas para o exercício do direito de ação, sob pena de estimular a litigância frívola e despropositada.

Para citar como exemplo uma questão controvertida, afirma-se que a banalização da concessão da gratuidade da justiça, sem mínimos critérios objetivos em sua aferição, pode favorecer o litigante aventureiro, que enxerga nos baixos custos da demanda judicial uma possibilidade mínima e eventual de benefícios econômicos. Um raciocínio comum, embora não o único ou o predominante, na avaliação do caminho para a solução de um conflito pela via judicial é o da sua viabilidade econômica, ou seja, se com a ação o autor poderá maximizar os ganhos e minimizar os custos. Assim, a banalização da gratuidade da justiça, ao reduzir os custos do processo judicial, favorece em certos termos a judicialização dos conflitos. ${ }^{5}$

\footnotetext{
${ }^{4}$ Nesse sentido, salienta Rodolfo de Camargo Mancuso: "O inc. XXXV do art. 5. ${ }^{\circ}$ da vigente $\mathrm{CF} / 1988$, dispondo que a lei não pode subtrair à apreciação judicial históricos de lesão sofrida ou temida, tem merecido, ao longo do tempo, uma leitura que a descolou da realidade judiciária contemporânea, tomando ares tão ufanistas como irrealistas. Com isso, daquele singelo enunciado se têm extraído premissas, garantias, deveres, direitos, enfim, proposições diversas, contando-se, dentre essas ilações exacerbadas: a garantia de acesso à Justiça, a universalidade da jurisdição, a ubiquidade da justiça, tudo, ao fim e ao cabo, estimulando o demandismo judiciário e por pouco não convertendo o direito de ação em ... dever de ação!" (MANCUSO, Rodolfo de Camargo. Acesso à justiça: condicionantes legítimas e ilegítimas. São Paulo: Revista dos Tribunais, 2011, p. 194).

${ }^{5}$ De Acordo com pesquisa realizada pela Pontifica Universidade Católica do Rio Grande do Sul "um dos motivos que levam os indivíduos a buscarem a prestação jurisdicional é o baixo risco envolvido no procedimento judicial, e de que esses motivos estão vinculados aos benefícios da Assistência Judiciária
} 
A percepção equivocada do papel do Judiciário como via prioritária de resolução dos conflitos interpessoais ocasionaram a expansão das demandas judiciais, com o estabelecimento de uma verdadeira "cultura do litígio processual". ${ }^{6}$ Essa realidade pode ser inferida do número de demandas que tramitam no Judiciário brasileiro e da tendência predominante de buscar a solução dos conflitos cotidianos em um processo judicial de cunho adversarial. ${ }^{7}$ No entanto, fica cada vez mais clara a insustentabilidade do atual nível de litigiosidade processual, o que exige, para além do fortalecimento do Poder Judiciário, políticas tendentes a estimular uma renovação da compreensão do próprio acesso à justiça.

Embora sejam bem compreendidas as distintas ideias de acesso ao Poder Judiciário e de acesso ao Direito ou à Justiça, ainda se constata uma ligação muito próxima da solução dos conflitos com a função jurisdicional do Estado, como se o direito perseguido por pessoas em litígio devesse necessariamente ser declarado pelo Poder Judiciário para gozar de validade jurídica. Em função disso, diferentemente do que se verificava no período de redemocratização do país, hoje não se encontra grande dificuldade para provocar o Judiciário, mas isso não se refletiu em um ganho proporcional na satisfação das demandas judiciais. Tornou-se mais fácil ingressar no Judiciário e mais difícil sair dele.

Nessa compreensão, cria-se um ambiente no qual os indivíduos são subliminarmente incentivados a renunciar ao poder de autodeterminação e de autogestão dos conflitos, transferindo para o Estado a responsabilidade pela condução de suas relações jurídicas. O Poder Judiciário assume uma postura paternalista de cunho

Gratuita". (PONTIFICA UNIVERSIDADE CATÓLICA DO RIO GRANDE DO SUL. Demandas judiciais e morosidade da Justiça Civil: Relatório final. Porto Alegre: CNJ, 2011, p. 77).

${ }^{6}$ Avalia Márcia Terezinha Gomes Amaral: "Realmente a incidência de conflitos está aumentando visivelmente na sociedade. De um lado, por falta de tempo as pessoas estão se tornando individualistas, deixando de dialogar com os outros, além da perda dos laços de solidariedade, o que gera uma incompreensão entre os indivíduos. De outro lado, a sociedade vivencia novos conflitos, em decorrência das transformações sociais, econômicas e políticas, do crescimento excessivo da população urbana, da industrialização, do grande contingente de desempregados, do surgimento de novas tecnologias, do elevado índice de violência, fazendo com que os conflitos tenham alto grau de complexidade". (AMARAL, Márcia Terezinha Gomes. O direito de acesso à justiça e a mediação. Rio de Janeiro: Lumen Juris, 2009, p. 39)

${ }^{7}$ Os números da litigiosidade nacional apresentados no Justiça em Números indicam tal cenário. (Conselho Nacional de Justiça. Justiça em números 2021. Brasília: CNJ, 2021, p. 102 e SS). 
prejudicial por cercear a emancipação dos indivíduos como cidadãos conscientes e capazes no exercício da vida social.

O caminho ideal em um Estado Democrático de Direito é exatamente o oposto. Ao assumir a possibilidade de uma solução negocial dos conflitos, os indivíduos exercitam a cidadania e participam ativamente da construção jurídica das relações intersubjetivas. Passam a ser os atores da pacificação social pretendida pelo Estado, atuando de forma descentralizada, o que permitiria um enraizamento em setores aos quais o Estado não consegue chegar.

Apesar desses benefícios, há uma dificuldade na mudança de perspectiva por parte dos próprios jurisdicionados. De um lado, porque a cultura da litigiosidade processual está instaurada de forma muito profunda na consciência popular. De outro lado, em razão do desconhecimento e do descrédito de outros meios de solução dos conflitos, especialmente dos mecanismos consensuais destinados a estimular a autocomposição e daqueles desenvolvidos extrajudicialmente. ${ }^{8}$

\section{ALGUMAS PERSPECTIVAS HISTÓRICAS DA ORIGEM DA PREPONDERÂNCIA DA FUNÇÃO JURISDICIONAL NA SOLUÇÃO DOS CONFLITOS NO BRASIL}

Definir como se chegou a essa "cultura de litigiosidade processual" é uma tarefa difícil, principalmente pela multiplicidade de fatores colaboram para sua construção. Uma das variáveis é certamente de cunho histórico, por isso impõe-se uma rápida reflexão sobre as raízes da formação do Judiciário no Brasil. Ao se desenvolver um tema tão controverso quanto as bases filosóficas de construção do Judiciário, é

\footnotetext{
${ }^{8}$ Nuria Belloso Martín indica possíveis motivos para essa cultura: “a) ausência da cultura da transação: os conflitos pretendem dirimir-se por via heterocompositiva e não por via autocompositiva; $b$ ) tendência a que todos os problemas dos cidadãos sejam resolvidos pelos poderes públicos; c) complexidade cada vez maior da vida social, especialmente no âmbito mercantil; d) exigência por parte dos cidadãos no exercício de seus direitos e interesses legítimos; e) crescente protagonismo social, político, jurídico e econômico do Poder Judiciário; f) excessivo protagonismo do Estado e ausência de regulação jurídica que convide os cidadãos a procurarem vias alternativas de resolução de conflitos; g) utilização do processo como forma de "vingança social"'. (MARTÍN, Nuria Belloso. A mediação: a melhor resposta ao conflito? In: SPENGLER, Fabiana Marion; LUCAS, Douglas Cesar (org.). Justiça restaurativa e mediação: políticas públicas no tratamento dos conflitos sociais. Ijuí: Unijuí, 2011. p. 317-355, p. 320).
} 
necessário evidenciar, logo de início, a importância inarredável desse Poder no desenvolvimento do Estado Democrático de Direito e na preservação dos direitos fundamentais. Ademais, é necessário registrar que a leitura histórica do processo evolutivo não pode ser analisada fora do contexto político de cada época, mas suas consequências marcam as diversas etapas evolutivas e influenciam a concepção atual, razão pela qual não podem ser desconsideradas.

Ainda que não haja uma homogeneidade no processo evolutivo dos diversos modelos jurisdicionais adotados no Brasil, é possível extrair alguns fortes indícios de finalidades assumidas de forma menos ostensiva pela função judicial para além da propalada pacificação social e garantia da ordem pública.

Ainda na época colonial, dado o controle exercido pela metrópole sobre a colônia, os representantes jurídicos de Portugal no Brasil dedicavam-se mais às funções políticas do que propriamente à realização da Justiça. A prioridade era a manutenção da estrutura de poder instituída por Portugal, de modo que o Judiciário no Brasil surge como um reflexo do poder totalitário da Coroa portuguesa, destinado prioritariamente a efetivar um controle social repressivo que assegurasse a unidade de poder. ${ }^{9}$ O Judiciário centralizava a resolução dos conflitos que importavam para a manutenção do poder do Estado e os interesses da Coroa.

Outro traço muito distintivo desse propósito pode ser deduzido da formação jurídica dos primeiros magistrados que atuaram no Brasil. Isso porque, na época, o ensino jurídico assumia uma postura utilitarista e voltada para a instrumentalização dos poderes do Estado. A Universidade de Coimbra, responsável pela formação dos juristas que atuaram nos três primeiros séculos pós colonização portuguesa, e as primeiras universidades brasileiras destinavam-se a formar funcionários do governo capazes de impor o controle social. ${ }^{10}$

\footnotetext{
${ }^{9}$ Stuart Schwartz explica que: "da mesma forma que em Portugal, onde os letrados eram o braço direito do absolutismo real, no Brasil eles eram usados para controlar as forças centrípetas geradas por específicos interesses". (SCHWARTZ, Stuart B. Burocracia e sociedade no Brasil Colonial: A Suprema Corte da Bahia e seus juízes. 1601-1751. São Paulo: Perspectiva, 1979, p. 291).

${ }^{10}$ Para José Murilo de Carvalho: "tratava-se [os juízes e magistrados] de uma elite sistematicamente treinada, sobretudo graças ao ensino do direito na universidade de Coimbra, fundada em 1290". O autor explica que o direito ensinado em tal universidade era de tradição romana antiga, por isso muitas vezes
} 
A devoção ideológica e submissão hierárquica desses magistrados à Coroa portuguesa tinha por trás, em grande parte das situações, a evolução em uma carreira política pautada por uma burocracia que focava um status social elitista e, muitas vezes, a perspectiva de retorno à metrópole.

Esse sistema, extremamente eficaz em seu propósito, teve como reflexos a utilização do processo judicial como uma ferramenta de restrição da autonomia das partes e como um mecanismo de contenção de interesses dissidentes, questões que acompanharão o Judiciário por muito tempo. Assim, já nesse embrião do Judiciário brasileiro, verifica-se um contexto de centralização do poder de solução dos conflitos, no qual a autonomia privada é desestimulada.

Assim, é certo que, nos primórdios da formação histórica do Judiciário no Brasil, sua função primordial não se constituía, em essência, no atendimento dos anseios de justiça da população ou da solução justa de conflitos cotidianos, mas, antes, era uma ferramenta de controle social e de manutenção do Poder. Por esse motivo, o Poder Judiciário tinha em sua essência o caráter centralizador e pautado preponderantemente nas decisões adjudicadas em substituição da vontade das partes. Era necessário que os conflitos, em especial os relevantes, fossem decididos por representantes do Estado para garantir que seguissem as direções definidas pela política central. O processo assumia um caráter inquisitorial, comum em processos absolutistas dos séculos XVII e XVIII que ressaltavam os interesses do soberano sobre os interesses das partes.

Com o tempo, essa postura desviada desencadeou problemas de inefetividade quanto à pacificação social esperada pela sociedade, o que favoreceu que críticas ao sistema fossem ouvidas e, em alguns pontos, consideradas. ${ }^{11}$ Todavia, somente na

serviria para embasar e reafirmar as "pretensões de supremacia dos reis". (CARVALHO, José Murilo de. A construção da ordem/teatro de sombras. 2. ed. Rio de Janeiro: Relume Dumara, 1996, p. 32).

${ }^{11}$ Maria Tereza Sadek adverte: "Desde as primeiras cortes, criadas ainda no período colonial, vozes se levantaram mostrando sua inoperância e o quanto distavam de um modelo de justiça minimamente satisfatório. Nos últimos tempos, entretanto, tornou-se dominante a idéia de que essas instituições, além de incapazes de responder à crescente demanda por justiça, tornaram-se anacrônicas e, pior ainda, refratárias a qualquer modificação". (SADEK, Maria Tereza. Judiciário: mudança e reformas. Estudos Avançados, São Paulo, v. 18, n. 51, p. 79-101, maio/ago. 2004, p. 83). 
primeira metade do século XIX começou a ganhar corpo a base teórica necessária para a superação desse modelo. ${ }^{12}$

No período pós Proclamação da República, percebe-se uma pequena oxigenação do sistema, tornando a centralização menos evidente. No entanto, a mudança foi lenta e gradual, em especial pela sobrevida de alguns aspectos do modelo de processo inquisitorial em períodos ditatoriais vivenciados no Brasil. Ainda assim, pouco a pouco, a bandeira da pacificação social passou a ser erguida em patamar mais elevado, até que essa finalidade passou a ser proclamada de forma patente. Todavia, ainda que de maneira velada, a posição do Judiciário como ferramenta de controle e de padronização social não foi abandonada por completo.

Com o advento do Estado Liberal e a valorização da liberdade, a autonomia privada passa a ser objeto de discussão jurídica no âmbito processual em uma forma de flexibilização da concepção publicista exacerbada do processo. ${ }^{13}$ Não se está aqui tratando de perspectivas extremistas de um estado mínimo pautado nos excessos do liberalismo econômico absoluto. É certo que também existiram excessos nessa compreensão da posição mais ativa das partes no processo, com tendências a relativizar o caráter público do processo, mas não prevaleceram.

Nesse momento, o processo judicial começa a ser percebido como ambiente para a garantia da liberdade individual, com a consagração do devido processo legal como uma proteção ao arbítrio estatal. ${ }^{14}$ Todavia, a noção de dependência do Poder Judiciário construída nos primeiros séculos da história do Brasil não poderia ser superada em poucos anos de experiências democráticas.

Os reflexos econômicos mundiais vivenciados no século $\mathrm{XX}$ oriundos dos impactos das guerras mundiais deram ensejo à construção de um "Estado Social". Sem adentrar no caráter semanticamente aberto que essa expressão possui e nos muitos matizes que ela assumiu na história do Brasil, por fugir ao objeto ora estudado, é certo que também colaborou para a cultura do litígio processual.

\footnotetext{
12 BARBOSA MOREIRA, José Carlos. O problema da divisão de trabalho entre juiz e partes: aspectos terminológicos. In: Temas de direito processual. São Paulo: Saraiva, 1989, p. 39.

${ }^{13}$ PRATA, Ana. Tutela constitucional da autonomia privada. Coimbra: Almedina, 1982, p.12.

14 WAMBIER, Luiz Rodrigues. Anotações sobre o princípio do devido processo legal. Revista do Tribunais. Ano 78-Ago. Vol. 647. São Paulo: Revista dos Tribunais, 1989, p; 37.
} 
A concessão de direitos sociais de forma geral e abstrata aliada a incapacidade de o Estado atendê-los de forma plena acarretaram a busca do Judiciário para fazer cumprir o que as normas previam. Mais uma vez o indivíduo se via como incapaz de resolver por conta própria os conflitos que o envolviam, precisando socorrer-se ao Estado para fazer valer seus direitos, mesmo que em face do próprio Estado.

Somente com a redemocratização e com o advento da Constituição de 1988, o Poder Judiciário passou a buscar de forma mais intensa uma desvinculação do objetivo de controle social. Mas, como esperado, a posição do Poder Judiciário quanto ao protagonismo da solução de conflitos não mudou de imediato. Na verdade, ele verificou um cenário favorável para crescimento em tamanho e em importância perante os outros Poderes.

A leitura constitucional do direito processual, feita de forma mais intensa já no início do século XXI, trouxe outro matiz para a posição das partes no processo e sua relação com o juiz. A questão estava relacionada a busca de um equilíbrio de forças entre as partes e o juiz, no qual não se estabeleça o protagonismo de um ou de outro, mas no entendimento de que o processo se desenvolve para as partes e que a elas deve ser reconhecido um nível de decisão. É preciso entender que o processo para ser um ambiente de garantia de direitos não precisa restringir totalmente a liberdade das partes $^{15}$.

Nessa toada, o Código de Processo Civil de 2015 pode ser destacado como outro marco nessa evolução. Com ele consagraram-se em definitivo as normas constitucionais como alicerce axiológico da legislação processual. ${ }^{16} \mathrm{Um}$ dos aspectos que merece

\footnotetext{
${ }^{15}$ Como ressaltar Igor Raatz: "É clara que a autonomia privada também sofre limites, mormente quando se ingressa no campo processual. Mas o fato de o processo ter caráter público não significa que ele seja capaz de consumir a liberdade e a autonomia das partes" (RAATZ, Igor. Autonomia privada e processo: liberdade, negócios jurídicos processuais e flexibilização procedimental. $2^{\mathrm{a}}$ edição. Salvador: Juspodivm, 2019, p. 177).

16 "Ao disciplinar que o CPC será aplicado de acordo com as normas fundamentais, ou seja, com os direitos fundamentais previstos na Constituição o art. 1. ${ }^{\circ}$ claramente atualiza o estudo do processo e a aplicação do Código ao estabelecer a Constituição como parâmetro operacional e interpretativo. Logo, atualmente, nenhum livro em matéria processual pode ser iniciado sem fazer recurso a um estudo preliminar acerca dos direitos fundamentais e suas implicações para a atuação jurisdicional por meio das técnicas e institutos regidos pelo novo Código" (DIAS, Jean Carlos; HOMCI, Arthur Laércio; MOUTA, José Henrique et al. Curso de processo civil: processo de conhecimento de acordo com o novo CPC. Rio de Janeiro: Lumen Juris, 2016, p. 6).
} 
destaque é o fato de o CPC abordar de forma estrutural e sistemática a autonomia privada no âmbito processual, o que pode ser percebido, por exemplo, com o estabelecimento normativo da promoção da solução consensual de conflitos, da cooperação e dos negócios processuais.

Esse conjunto de fatores históricos, políticos e filosóficos representam alguns dos elementos que compõem a complexa estrutura cultural que fundamenta a tendência de delegação de poder decisório ao Judiciário e a restrição a outros meios de solução de conflitos. A consequência é o conhecido elevado índice de litigiosidade judicial no Brasil.

\section{AS DIFICULDADES DA MUDANÇA NA POLÍTICA JUDICIÁRIA DE TRATAMENTO DOS CONFLITOS}

Diante de um contexto histórico e de uma base legal tão consolidada na solução judicial dos litígios, o aperfeiçoamento do sistema de Justiça não pode ser alcançado com o simples aparelhamento do Judiciário destinado a elevar sua capacidade de tramitação e de julgamento dos processos. Enquanto perdurar a cultura do litígio processual, quanto maior for a capacidade de julgamento, maior será o número de novas ações propostas. Portanto, a questão precisa ser avaliada sob outra perspectiva e com base em outros valores.

Existem duas formas principais de aprimorar um processo de trabalho. Uma delas, a mais óbvia, é ampliar os recursos físicos e de pessoal empregados na produção. Essa via foi e continua sendo utilizada quase à exaustão e, sozinha, não resolveu e tudo indica que não resolverá o problema de forma integral. Já ficou claro que as restrições orçamentárias limitam a capacidade de crescimento da estrutura física, do desenvolvimento tecnológico e de pessoal do Poder Judiciário no mesmo ritmo da evolução da demanda, sem que isso importa em uma queda na qualidade da prestação jurisdicional.

Destaca-se daí a outra forma de aperfeiçoamento do processo de trabalho. Tratase da revisão das rotinas, do redesenho de procedimentos, da revisão do método de 
trabalho e do aprimoramento tecnológico em prol de maior eficiência. ${ }^{17}$ Nesse ponto, foram registrados significativos avanços nos últimos anos e ainda existe margem para o ganho de eficiência no serviço público, em especial com a incorporação de novas tecnologias, mas o ganho de produtividade alcançado por essa via também é limitado.

A análise desse cenário permite constatar que o abuso do direito de ação é tão danoso quanto as restrições ao seu exercício. É uma falácia defender que se realiza o espírito do acesso à justiça com a pretensão de resolução de todo e qualquer conflito com repercussão jurídica ao albergue do Poder Judiciário.

A verdade é que as duas dimensões do acesso à justiça interferem, posto que o volume de demanda impacta a capacidade de apresentação de uma solução construída com qualidade e em tempo razoável. Se os magistrados pudessem concentrar seus esforços nas demandas que verdadeiramente exigem uma manifestação substitutiva da vontade das partes haveria um incremento de efetividade, realizando o elemento conclusivo do acesso à justiça. ${ }^{18}$

Para afastar dúvidas sobre a posição adotada, mesmo com risco de pecar pela redundância, frisa-se que a defesa de uma revisão nos limites do acesso à justiça é feita em prol de uma racionalização da judicialização dos conflitos, evitando-se excessos para qualquer dos extremos. É necessário equilíbrio.

O reconhecimento da efetividade de outras formas de solução de conflitos distintas da jurisdição não implica o declínio da resolução do conflito adjudicada mediante uma sentença, nem tampouco a privatização do processo judicial ou muito menos uma restrição ao acesso à justiça. Ao contrário, o acesso é potencializado pelo reconhecimento de outras vias de inclusão com características diferentes. ${ }^{19}$

\footnotetext{
${ }^{17}$ Como pontua Érica Barbosa e Silva: “A universalização do acesso à Justiça precisa ser compatibilizada com as limitações do Estado e, mais especificamente, do Poder Judiciário. Não basta, portanto, ampliar o número de juízes ou da estrutura do Judiciário, mas é processo desenvolver uma nova política de tratamento dos conflitos". (SILVA, Érica Barbosa e. Conciliação judicial. Brasília, DF: Gazeta Jurídica, 2013, p. 30).

18 José de Albuquerque Rocha: "Se os conflitos podem ser resolvidos extrajudicialmente pelos próprios litigantes, deixa-se para o magistrado apenas os litígios que efetivamente exigem a prolação de uma decisão judicial. Com isso, o juiz tem mais tempo para se dedicar à resolução desses litígios". (ROCHA, José de Albuquerque. Instituições arbitrais. In: SALES, Lília Maia de Morais (org.). Estudos sobre mediação e arbitragem. Rio de Janeiro: ABC Editora, 2003, p. 97).

${ }^{19}$ Assim pondera Isabela Medeiros: "Destarte, pode-se afirmar que a ideia de acesso à justiça vinculada estritamente ao Judiciário é limitada e, sobretudo, obsoleta, merecendo ser suplantada. Deve ceder,
} 
Expressões como "vou processar você" ou "vou procurar os meus direitos na justiça" tornaram-se a exteriorização mais usual da busca de Justiça, embora, na maioria das vezes, acirrem o conflito quando dito no auge do debate. ${ }^{20}$ Essa correlação expressa a visão limitada que os litigantes tem sobre os caminhos que podem seguir, uma vez que não conseguem avaliar a diversidade de métodos de solução para os conflitos e ignoram o poder de decisão que possuem, se assumissem posturas mais racionais e propositivas.

Nesse contexto de ineficiência do aparelho jurisdicional para determinadas demandas, os outros métodos de solução de conflitos - em especial os meios autocompositivos - representam uma forma complementar de resguardar o acesso à justiça.

A situação impõe uma mudança na forma de pensar a solução do conflito. Não se pode continuar com o foco quase exclusivo no aprimoramento e na ampliação de uma estrutura que, em essência, não é capaz por si só de atender aos anseios. É preciso superar a solução dada com base em esquemas jurídicos defasados diante da realidade que evoluiu e exige uma perspectiva diferente. Ocorre que, a superação de uma cultura consolidada não ocorre de forma rápida. Para que floresçam novos hábitos é preciso apresentar e exercitar novos olhares até que eles sejam gradualmente incorporados no subconsciente popular. ${ }^{21}$

portanto, lugar a uma conotação mais ampla, que ocupa um lugar de destaque no Estado contemporâneo, extrapola os limites judiciais e toma a cena de outras esferas. Desta forma, muito embora deva se considerar a importância dos instrumentos processuais de acesso à justiça, não parece adequado restringir este instrumental ao Judiciário, uma vez que, conforme já salientado, a ideia de acesso à justiça aparelhase com a efetivação dos direitos fundamentais, não havendo como restringir tal acesso a questões processuais". (MEDEIROS, Isabela. Assistência jurídica gratuita: cidadania e emancipação. Rio de Janeiro: Lumen Juris, 2013, p. 15-16).

${ }^{20}$ Nas palavras de Patrícia Freire de Paiva Carvalho Rabelo e Soraya Vieira Nunes: "O acesso à Justiça passou a ser até mesmo forma de ameaça durante uma discussão, quando ainda inflamados pelos sentimentos negativos que afloram durante o conflito, e uma das pessoas envolvidas em vez de tentar se acalmar e conversar em outro momento já eleva o tom de voz para dizer que irá procurar os seus direitos". Essa postura combativa acaba por abrasar ainda mais os ânimos e, muitas vezes, põe fim ao debate acirrado sem que haja nova tentativa de restaurá-lo. O próximo encontro acaba sendo em uma mesa de audiência no Poder Judiciário". (RABELO, Patrícia Freire de Paiva Carvalho; NUNES, Soraya Vieira. A mediação como forma de resolução de conflitos: uma análise crítica do CPC/15 à luz da Lei 13.140/2015. In: PEIXOTO, Renata Cortez Vieira; SOUSA, Rosalina Freitas Martins de; ANDRADE, Sabrina Dourado França (coord.). Temas relevantes de Direito Processual Civil: elas escrevem. Recife: Armador, 2016. p. 31-44, p. 32)

${ }^{21}$ Como advertem Lília Maia de Morais Sales e Marília Bitencourt Calou: "Depois de séculos (ou mesmo milênios) de submissão a decisões totalitárias é normal a arraigada sedimentação de cultura nesse sentido. As consequências psicológicas da inquisição, imposição e violência instituída não serão facilmente 
A resistência aos meios consensuais é fruto de uma visão distorcida que se construiu sobre eles. A falta de informação sobre as possibilidades e técnicas de gestão consensual de litígios gera uma equivocada noção de que a arbitragem e autocomposição extrajudicial, por exemplo, seriam uma saída de segunda classe. Essa concepção retrata uma retrógrada compreensão do processo, pela qual as partes seriam incapazes de solucionar o conflito de forma autônoma, dependendo necessariamente da intervenção estatal.

\section{A IMPLANTAÇÃO DE UM SISTEMA JUDICIAL MULTIPORTAS NO BRASIL E AS DIFICULDADES PARA A PROMOÇÃO DAS VIAS AUTOCOMPOSTIVAS}

Em busca de alternativas, dentre os exemplos que podem orientar a construção de novos caminhos à forma tradicional de prestação jurisdicional brasileira, destaca-se o modelo de abertura do Judiciário a outros meios de solução de conflitos desenvolvido nos Estados Unidos. Atribui-se como marco inicial dessa mudança o simpósio jurídico ocorrido em 1976 em celebração do septuagésimo aniversário do discurso de Roscoe Pound sobre as causas da insatisfação popular com a administração da justiça (The Causes of Popular Dissatisfaction with the Administration of Justice).

Por ocasião desse evento, no qual se discutia a ineficácia do sistema de Justiça até então vigente e as alternativas de superação da crise, uma das principais propostas foi a apresentada por Frank Ernest Arnold Sander, que sugeria a instituição de uma unidade que congregasse meios variados de resolução de conflitos, tanto heterocompositivos como autocompositivos.

Essa unidade, inicialmente denominada pelo autor "Centro de Justiça Global" (Comprehensive Justice Center), acabou popularizando-se como "Fórum de Múltiplas

expurgadas do inconsciente individual. Necessário se faz este eficaz primeiro modelo de mediação para remodelamento de novos paradigmas para as gerações vindouras que continuarão a contribuir para o processo de total empoderamento individual a despeito dos modelos inquisitoriais de submissão". (SALES, Lília Maia de Morais; CALOU, Marília Bitencourt C. A cultura da mediação e a contraposição de paradigmas: uma análise da cooperação e autonomia na resolução de conflitos. Revista Eletrônica Direito e Política, Itajaí, v. 12, n. 3, p. 1290-1313, 3. quadr. 2017, p. 1303). 
Revista Eletrônica de Direito Processual - REDP.

Rio de Janeiro. Ano 16. Volume 23. Número 1. Janeiro a Abril de 2022

Periódico Quadrimestral da Pós-Graduação Stricto Sensu em Direito Processual da UERJ

Patrono: José Carlos Barbosa Moreira (in mem.). ISSN 1982-7636. pp. 1021-1052

www.redp.uerj.br

Portas" (Multi-Door Courthouse), expressão que retratava de forma mais didática a proposta do autor. Com isso, o professor da Harvard Law School conseguiu unir a necessidade de aprimoramento da prestação jurisdicional às vantagens da gestão consensual de conflitos. ${ }^{22}$

É importante destacar a percepção do autor da conveniência da ligação dessa unidade de múltiplas portas com o Poder Judiciário, dada a procura natural pelas Cortes de Justiça como local de resolução de conflitos. ${ }^{23}$ Essa realidade é similar com a que atualmente se vivencia no Brasil.

Em breves linhas, a proposta desenvolvida por Frank Sander consiste em disponibilizar, no âmbito do Poder Judiciário, uma diversidade de métodos e técnicas para a gestão do conflito. Com isso, a apreciação jurisdicional, até então a porta quase

${ }^{22}$ Relata Brian Preston: “[...] a solução proposta por Sander de um centro de resolução de disputas que oferece uma panóplia de serviços de resolução de disputas abordou os dois temas de preocupação subjacentes às causas de insatisfação de Pound, em primeiro lugar, combinando mecanismos de resolução de disputas com as características individuais das disputas e, em segundo lugar, reformando o sistema dos tribunais e seus procedimentos". No original: “[...] Sander's proposed solution of a dispute resolution centre offering a panoply of dispute resolution services addressed the two themes of concern underlying Pound's causes of dissatisfaction by, first, matching dispute resolution mechanisms to the individual characteristics of disputes and, secondly, by reforming the system of courts and their procedures". (PRESTON, Brian. The Land and Environment Court of New South Wales: moving towards a multi-door courthouse. Australasian Dispute Resolution Journal, v. 19, n. 3, p. 144-155, Aug. 2008. Disponível em: http://www.bocsar.nsw.gov.au/lawlink/lec/ll_lec.nsf/vwFiles/Paper_15Nov07_Preston_LEC_Multi_door _Court.doc/\$file/Paper_15Nov07_Preston_LEC_Multi_door_Court.doc. Acesso: 20/03/2021).

${ }^{23}$ Nas palavras de Mariana Hernandez Crespo e Frank Sander: "O tribunal é onde estão os casos, por isso é natural ter o tribunal como uma porta do tribunal de múltiplas portas - essa é a ideia. Mas o tribunal poderia estar aqui e os outros processos [arbitragem, mediação, etc.] poderiam estar ali; não há nada inerente [ao esquema] que impeça isso. Não existe uma relação inerente. Penso que, por outro lado, é um relacionamento bastante natural porque os tribunais são o nosso principal, talvez o nosso mais importante, lugar de resolução de disputas. Assim, pode-se argumentar fortemente que o tribunal de múltiplas portas deveria estar conectado com os tribunais, mas, tecnicamente, o centro de justiça abrangente [ou tribunal de múltiplas portas] que mencionei poderia ser bastante separado dos tribunais". (Tradução nossa) No original: "The court is where the cases are, so it is natural to have the court as one door of the multi-door courthouse - that is the idea. But, it could be that the court could be over here and the other processes [arbitration, mediation, etc.] could be over there; there is nothing inherent [in the scheme] that prevents this. There is no inherent relationship. I think, on the other hand, it is a pretty natural relationship because courts are our main, perhaps our most important, dispute-resolution place. So, one can make a strong argument that the multi-door courthouse ought to be connected with the courts, but technically the comprehensive justice center [or multi-door courthouse] that I mentioned could be quite separate from the courts". (CRESPO, Mariana Hernandez; SANDER, Frank. A dialogue between Professors Frank Sander and Mariana Hernandez Crespo: exploring the evolution of the multi-door courthouse (Part One). University of St. Thomas Law Journal, Saint Paul, MN, v. 5, n. 3, p. 665-674, 2008. Disponível em: http://papers.ssrn. com/sol3/papers.cfm?abstract_id=1265221. Acesso: 15/03/2021, p. 671. 
exclusiva no âmbito do Judiciário, passa a ser ladeada por outras "portas" de acesso à gestão do conflito, como a mediação, a conciliação e a arbitragem. ${ }^{24}$

O funcionamento desse sistema pressupõe dois aspectos basilares. Primeiramente, é necessário que o Judiciário disponibilize o acesso de forma satisfatória às outras vias de gestão de conflito. Por exemplo, se o caso indica o cabimento de uma autocomposição, deve haver salas e profissionais qualificados e em número suficiente para sua recepção.

Em segundo lugar, é preciso um setor de triagem que utilize critérios racionais e objetivos para definir a destinação mais adequada da causa a cada uma das portas disponíveis. A ideia é que um profissional capacitado para essa avaliação, que compreenda bem o cabimento dos métodos heterocompositivos e autocompositivos, avalie as especificidades da causa e das partes e direcione a demanda para o mecanismo de gestão mais eficaz. ${ }^{25}$

Como se observa nos pontos mencionados, é possível estabelecer uma relação parcial entre os fundamentos do movimento norte-americano e a realidade vivenciada atualmente no Brasil. Logicamente, existem elementos históricos, políticos, filosófico e culturais que distiguem as duas realidades, mas a insatisfação popular com a Justiça e a ineficiência da reforma constitucional do Judiciário aproximam, em certos termos, a conjuntura dos dois países, a despeito do lapso temporal entre ambos.

Diante disso, é possível imaginar que algumas das repostas dadas aos problemas naquele país, devidamente ajustadas e adequadas à realidade nacional, podem também

\footnotetext{
24 De acordo com Valéria Ferioli Lagrasta Luchiari, "O Fórum de Múltiplas Portas ou Tribunal Multiportas constitui uma forma de organização judiciária na qual o Poder Judiciário funciona como um centro de resolução de disputas, com vários e diversos procedimentos, cada qual com suas vantagens e desvantagens, que devem ser levadas em consideração, no momento da escolha, em função das características específicas de cada conflito e das pessoas nele envolvidas”. (LUCHIARI, Valeria Ferioli Lagrasta. Histórico dos métodos alternativos de solução de conflitos. In: GROSMAN, Cláudia Frankel; MANDELBAUM, Helena Gurfinkel (org.). Mediação no Judiciário: teoria na prática e prática na teoria. São Paulo: Primavera Editorial, 2011b. p. 283-320, p. 308).

${ }^{25}$ Nesse sentido, Walsir Edson Rodrigues Júnior afirma: “O acesso à Justiça não é visto, naquele país, como um 'direito social', mas, antes, como um problema social, tanto que os meios alternativos de resolução de conflitos passaram a ser objeto de cursos básicos em Faculdades de Direito. No âmbito do Poder Judiciário, foi criado um sistema de multiportas, ou seja, aos litigantes são oferecidas diferentes alternativas para resolução de suas disputas. É realizado um diagnóstico prévio do litígio, posteriormente encaminhado por meio do canal mais adequado a cada situação". (RODRIGUES JÚNIOR, Walsir Edson. A prática da mediação e o acesso à justiça. Belo Horizonte: Del Rey, 2006, p. 67-68).
} 
ser eficazes aqui, trazendo o tema à atual pauta de discussões sobre as reformulações do sistema de Justiça. ${ }^{26}$

É bem verdade que os meios consensuais de gestão do conflito estão presentes nos processos judiciais nacionais a bastante tempo. A mediação começou a ser debatida na seara legislativa nacional ainda no final da década de 90 do século XX, com o Projeto de Lei da Câmara dos Deputados n. ${ }^{\circ}$ 4.827/1998. A primeira regulamentação da matéria, porém, demorou mais de uma década para vigorar e veio na forma da Resolução n. ${ }^{\circ}$ 125/2010 do Conselho Nacional de Justiça.

Todavia, foi somente no ano de 2015 que a mediação foi legalmente regulamentada, inclusive com o disciplinamento amplo da mediação judicial tanto na Lei n. ${ }^{\circ}$ 13.105/2015, que instituiu o novo Código de Processo Civil, quanto na Lei n. ${ }^{\circ}$ 13.140/2015, denominada Lei de Mediação. O Código vigente tem entre suas características mais marcantes a flexibilização procedimental e respeito a autonomia privada. Isso abre uma gama de variações no processo para torná-lo mais adequado às necessidades de cada caso concreto.

Todavia, o incentivo à autocomposição não pode ser encarado como a solução para os problemas do Judiciário. Os entraves do Poder Judiciário podem ser superados para alguns casos específicos e de forma reflexa beneficiar a prestação jurisdicional, mas não constituem a finalidade precípua da mediação e da conciliação. ${ }^{27}$ Os valores que fundamentam a solução consensual são outros, inclusive de natureza mais nobre.

\footnotetext{
${ }^{26}$ Como exemplo é possível mencionar a Directiva 2008/52/CE do Parlamento Europeu e do Conselho da União Europeia, na qual se definiu, para orientar os litígios transfronteiriços e a regulamentação interna pelos Estados-Membros, o objetivo de "promover a resolução amigável de litígios, incentivando o recurso à mediação e assegurando uma relação equilibrada entre a mediação e o processo judicial". Disponível em: http://eur-lex.europa.eu/legal-content/PT/TXT/?uri=CELEX\%3A32008L0052. Acesso: 02/012021.

${ }^{27}$ Kazuo Watanabe analisa essa possível distorção nos seguintes termos: "O objetivo primordial que se busca com a instituição de semelhante política pública é a solução mais adequada dos conflitos de interesse, pela participação decisiva de ambas as partes na busca do resultado que satisfaça seus interesses, o que preservará o relacionamento delas, propiciando a justiça coexistencial. A redução do volume de serviços do Judiciário é uma consequência importante desse resultado social, mas não seu escopo fundamental. Por meio dessa política pública judiciária, que proporciona aos jurisdicionados uma solução mais adequada dos conflitos, o Judiciário Nacional estará adotando um importante filtro da litigiosidade, que, ao contrário de barrar o acesso à justiça, assegurará aos jurisdicionados o acesso à ordem jurídica justa, e, além disso, atuará de modo importante na redução da quantidade de conflitos a serem ajuizados e também, em relação aos conflitos judicializados ou que venham a ser judicializados, a sua solução pelos mecanismos de solução consensual dos conflitos, o que certamente determinará a redução substancial da quantidade de sentenças, de recursos e execuções judiciais". (WATANABE,
} 
O que se pretende é garantir, quando possível, uma solução construída pelos próprios litigantes, com a superação do problema em um nível mais profundo do que aquele inicialmente apresentado em juízo e, com isso, construir nas partes o reconhecimento da capacidade de solucionar seus problemas, empoderando-as para o enfrentamento de controvérsias posteriores.

No necessário empenho pela valorização dos meios consensuais de solução de conflitos, deve ser evitada a demonização da solução da causa pela via jurisdicional. A mediação e a conciliação devem ser incentivadas por meio da valorização de suas qualidades, e não pelo destaque das deficiências das demais vias. Utilizar os problemas da jurisdição para convencer as partes a submeter-se a uma sessão de conciliação ou de mediação desvirtua o próprio sistema processual.

Nos casos em que a autocomposição não for alcançada, o conflito será levado a julgamento pelo magistrado. Nesse cenário, as críticas à solução adjudicada mediante sentença, incutidas nas partes em momento anterior, implicarão uma menor probabilidade de aceitação da decisão. Dessa forma, estarão intensificados os problemas de inefetividade da tutela jurisdicional já existentes, e o sistema processual, compreendido como um todo harmônico, estará enfraquecido.

Como se percebe, assim como a jurisdição não é uma solução para todo e qualquer conflito, a autocomposição, da mesma forma, também não o é. Está equivocada a prioridade acrítica dada aos meios autocompositivos expressa no brocardo popular segundo o qual "é melhor um mau acordo do que um bom processo". Os conflitos não devem ser tratados da mesma forma. O próprio $\mathrm{CPC}$, ao estabelecer o dever de promoção da solução consensual de conflito, adverte que tal estímulo só deve ser realizado quando for possível (art. $3^{\circ}, \S 2 .^{\circ}$ ). A questão central é, portanto, definir qual meio é o mais adequado ao caso concreto, de modo que a preferência só pode ser definida a partir do conflito.

Como o objetivo comum dos meios heterocompositivos e autocompositivos é a solução do conflito, ambos devem ser valorizados para que atinjam seus desideratos da

Kazuo. Política pública do Poder Judiciário nacional para tratamento adequado dos conflitos de interesses. In: PELUSO, Antonio Cezar; RICHA, Morgana de Almeida (coord.). Conciliação e mediação: estruturação da política judiciária nacional. Rio de Janeiro: Forense, 2011. p. 3-10, p. 4). 
forma mais eficaz quando acionados. Essa é a lógica por trás de um sistema multiportas. Somente com a compreensão da relação de complementaridade entre os métodos heterocompositivos e autocompositivos e da necessária adaptabilidade da "porta" escolhida às características do conflito e aos sujeitos, o sistema atingirá seus objetivos de forma eficiente.

\section{A COEXISTÊNCIA $E$ A INTERAÇÃO DAS VIAS JUDICIAIS E EXTRAJUDICIAIS DE SOLUÇÃO CONSENSUAL DE CONFLITOS}

Não basta que vias heterocompositivos e autocompositivos se complementem no âmbito judicial, é preciso haver também uma interação entre as vias judicias e extrajudiciais. A Justiça não é alcançada somente no âmbito do Poder Judiciário, existindo canais de igual importância fora do Judiciário. As vias extrajudiciais de gestão e solução de conflitos devem ser valorizadas, pois podem se apresentar como caminhos mais adequados para diversos casos concretos.

Como visto, ideia de um tribunal de múltiplas portas é importante para o desenvolvimento dessa noção, na medida em que o Poder Judiciário é um ponto de centralização da busca por solução de conflitos. No entanto, a questão não deve se restringir a essa abordagem, é preciso considerar que também se faz "justiça" fora e independentemente do Poder Judiciário. Por isso, o termo "justiça multiporta" tem sido cada vez mais utilizado. A relação de complementaridade entre as vias judiciais e as extrajudiciais é importantíssima para essa compreensão.

Ainda no âmbito dos métodos heterocompositivos, é necessário dar destaque à arbitragem. Trata-se de um procedimento no qual os interessados buscam o auxílio de um terceiro ou de um colegiado de pessoas, sem interesse na causa, para, respeitando um procedimento que assegure as garantias constitucionais do processo, prolatar uma decisão ${ }^{28}$.

\footnotetext{
28 José de Albuquerque Rocha define a arbitragem como "um meio de resolver litígios civis, atuais ou futuros, sobre direitos patrimoniais disponíveis, através de árbitro ou árbitros privados, escolhidos pelas partes, cujas decisões produzem os mesmos efeitos jurídicos das sentenças proferidas pelos órgãos do
} 
O CPC respeita essa autonomia, dialogando com a arbitragem em diversos pontos: o estimulo à sua adoção (art. $3^{\circ}, \S 1$ 1. $^{\circ}$, e art. 359 do CPC); respeito ao sigilo das questões que tramitem no Judiciário (art. 189, IV, do CPC); a carta arbitral (art. 260, § 3. ${ }^{\circ}$, do CPC); alegação da convenção de arbitragem na resposta do réu (art. 337, X); extinção do processo sem resolução de mérito quando constatada sua existência (art. 485, VII); qualificação da sentença arbitral como título executivo judicial (art. 515, VII, do CPC); etc. Dessa forma, no que concerne ao contato da arbitragem com o sistema judicial, os pontos principais já se encontram razoavelmente desenvolvidos.

Também merece referência a desjudicialização de algumas matérias como da retificação do registro imobiliário (Lei no 10.931/2004), do inventário, da separação e do divórcio (Lei $n^{\circ} 11.441 / 2007$ ), da retificação de registro civil (Lei ${ }^{\circ}$ 13.484/2017) e da usucapião instituída pelo Código de Processo Civil (art. 1.071 - LRP, art. 216-A). Vale mencionar ainda os debates cada vez mais intensos sobre a desjudicialização de aspectos da execução civil.

Como se percebe a questão é mais ampla e pode ser apreciada em perspectivas mais amplas e variadas. As ideias de fundo da justiça multiportas são o pluralismo e a adequação. É preciso que os litigantes disponham de um leque significativo de "portas" para acessar a justiça pelo meio que melhor se ajuste às suas peculiaridades e interesses.

A disponibilização de alternativas válidas e eficazes de solução dos conflitos deve não só contemplar diversas formas autocompositivas e heterocompositivas, como também garantir a aplicação dessas diversas formas dentro e fora do Poder Judiciário. Por mais importante que seja a participação do Poder Judiciário na promoção dos meios autocompositivos, o alcance máximo do estímulo à gestão consensual dos conflitos só será atingido com a ação integrada com as iniciativas extrajudiciais.

Nos últimos anos, em especial após a entrada em vigor do CPC/2015, tem sido observado um aumento na atenção dispensada aos meios de solução consensual de conflitos no âmbito judicial, o que é positivo em diversos aspectos, mas não pode ocorrer de forma isolada. Se todas as ações da Política Judiciária Nacional de tratamento

Poder Judiciário". (ROCHA, José de Albuquerque. Instituições arbitrais. In: SALES, Lília Maia de Morais (org.). Estudos sobre mediação e arbitragem. Rio de Janeiro: ABC Editora, 2003, p. 96-97). 
adequado de conflitos tiverem por foco exclusivo o âmbito judicial, é possível que uma das premissas consideradas sofra distorções.

As mediações e as conciliações extrajudiciais devem ser valorizadas, pois o empoderamento das partes e a valorização de sua autodeterminação tendem a reduzir a necessidade de intervenção do Estado na solução dos conflitos, mas essa valorização não afastará a necessidade de um terceiro que venha a auxiliar nas negociações. ${ }^{29}$

A correta realização de mediações e de conciliações exige, na maior parte dos casos, atendimentos diferenciados, tempo elevado, espaços que estimulem o diálogo e o protagonismo das partes, equipes multidisciplinares, etc. Ainda que os tribunais tenham evoluído, alguns desses aspectos encontram maior dificuldade de desenvolvimento no âmbito judicial do que no extrajudicial.

Para exemplificar essa dificuldade, é possível observar o desenvolvimento do estímulo ao protagonismo. Os fóruns do Poder Judiciário são vistos pela sociedade como local de manifestação do Poder Estatal, para onde as partes tradicionalmente vão à procura da solução dada por uma autoridade. Fazer com que as partes assumam a solução do conflito torna-se mais complicado. Por mais que as partes recebam a informação de que o mediador ou o conciliador judicial não julgará a causa, percebe-se uma reverência intimidadora em relação ao profissional que conduz o ato. Da mesma forma, mesmo que garantida a confidencialidade, assegurando-se que as informações apresentadas não serão levadas ao juiz, paira uma desconfiança inibidora da plena apresentação do conflito.

Isso não quer dizer que as mediações e conciliações extrajudiciais são necessariamente melhores do que as judiciais. Apenas indica que o âmbito extrajudicial pode apresentar-se mais adequado para as causas nas quais se tornem mais evidentes essas questões. Mais uma vez, não há uma concorrência entre o judicial e o extrajudicial, há antes uma relação de complementaridade que beneficia as partes. Elas passam a ter ao seu dispor uma variedade de vias com características distintas, entre as

${ }^{29}$ Fernanda Tartuce ressalta que: "A mediação privada oferece mais uma alternativa aos cidadãos para reduzir tempo e curto na solução de conflitos". (TARTUCE, Fernanda. Mediação nos conflitos civis.6. ed. São Paulo: Método, 2020, p. 280). 
quais podem escolher aquela que melhor atende aos seus interesses e às suas necessidades.

O problema é que a gestão dos conflitos no âmbito extrajudicial parece estar sendo preterida. A elevada atenção dada à autocomposição judicial transmite à sociedade a falsa noção de que essa via deve ser privilegiada, como se houvesse algo de mais efetivo ou benéfico nos acordos homologados judicialmente.

Se um dos propósitos da promoção da solução consensual de conflitos é fortalecer o autorregramento da vontade pelo empoderamento das partes, os acordos diretamente por elas celebrados devem ostentar força jurídica equivalente à das autocomposições homologadas judicialmente. Logicamente, precisam estar materializados em documentos que atendam os requisitos para se constituir como títulos executivos extrajudiciais.

O emblema do Poder Judiciário e a assinatura do juiz não podem ser entendidos pelos cidadãos como indispensáveis à validade das soluções que eles próprios, com ou sem auxílio de terceiros, encontram para os conflitos.

Da análise dos normativos, das decisões administrativas e das políticas públicas relacionadas à mediação judicial, é possível extrair uma tendência de centralização do Poder Judiciário na condução da implantação dos mecanismos de gestão consensual de conflitos no âmbito judicial. Fala-se em centralização no sentido do estabelecimento de requisitos e controles muito rígidos para o intercâmbio de práticas com instituições e pessoas alheias ao Poder Judiciário.

Como exemplos desse fechamento no campo da autocomposição cita-se o rigor elevado para a formação de instrutores em conciliação e mediação judicial, a formação e o credenciamento de conciliadores e mediadores, o credenciamento de instituições privadas para a formação de mediadores, o credenciamento das câmaras privadas de mediação.

É razoável que se tenha prudência na definição dos fluxos de trabalho que envolvam iniciativas públicas e privadas, de modo a resguardar a necessária probidade e imparcialidade inerentes à atividade judicial. Essas precauções, todavia, não se podem transmutar em bloqueios absolutos. Não se pode atribuir um pudor excessivo às relações 
e ações conjuntas entre instituições públicas e privadas como se estivessem maculadas de uma promiscuidade inerente.

Nesse ponto, importa destacar a importância de o Poder Judiciário dar espaço para o desenvolvimento de outras técnicas de gestão de conflito como forma de contribuir para o empoderamento dos cidadãos e para a assunção de responsabilidade pelas decisões. A troca de experiências e de práticas novas colabora para o amadurecimento da própria mediação e para o aprimoramento técnico dos profissionais que atuam na área. ${ }^{30}$

O isolamento do Poder Judiciário não faz sentido no contexto da justiça multiportas. Os acordos judiciais são apenas uma pequena fração do universo da autocomposição. Em razão dessa ligação indissociável, é improvável que se verifique o sucesso de uma parte isolada sem que o todo também se desenvolva satisfatoriamente. Portanto, a efetividade da conciliação e da mediação judicial depende do progresso delas também na via extrajudicial.

Por isso, não se justifica que as políticas judiciárias para a promoção da gestão consensual do conflito ignorem ou rechacem as iniciativas privadas e que as regulamentações normativas tentem apartar a mediação judicial das experiências extrajudiciais. A lógica que deve orientar a promoção da solução consensual de conflitos, em especial nesse primeiro momento, deve ser a de abertura, integração e pluralidade, com o estímulo das mais variadas experiências nos diversos âmbitos de sua manifestação.

Essa proposta já fazia parte da filosofia de Frank Sander no início do desenvolvimento da mediação nos Estados Unidos, com a ideia de "deixar mil flores desabrocharem". ${ }^{31}$ Deve-se incentivar uma ebulição de novas propostas, formas e experiências para possibilitar a expansão da mediação de forma horizontal e sustentável.

\footnotetext{
30 Ressalta Ricardo Goretti: “O engajamento de diferentes órgãos e instituições deve ser fomentado, inclusive para efeito de troca de experiências: prática que contribuirá sobremaneira para a qualificação e o amadurecimento das ações mediadoras no País". (GORETTI, Ricardo. Mediação e acesso à justiça. Salvador: Juspodivm, 2017, p. 289).

${ }^{31}$ Frank Sander, assim analisa a evolução da mediação: “O primeiro período, penso eu, foi de 1975 a 1982. Eu o chamo: 'Deixar mil flores desabrocharem' [...] O segundo período, de 1982 a 1990 - e essas datas são bem impressionistas da minha parte - eu chamo 'Cuidados e ressalvas': Preocupações sobre o que estamos fazendo, tentativas de separar o trigo da palha. [...] O terceiro período, começando em 1990,
} 
De acordo com a análise da evolução da mediação nos EUA feita por Frank Sander, percebe-se que foram necessários mais de 15 anos até que se consolidasse razoavelmente a institucionalização da mediação. Portanto, não é razoável esperar que a assimilação e a estruturação dessas práticas no Brasil ocorram de forma quase imediata. É certo que a mediação já é debatida no Brasil há alguns anos, mas, até 2015, o alcance das discussões e o número de ações ainda eram mais limitados, apesar das relevantes iniciativas realizadas.

Serão precisos mais alguns anos de intensa atividade para que os institutos previstos na legislação se consolidem e permitam uma real compreensão do seu alcance e da sua eficiência. Mesmo que o ordenamento brasileiro tenha aproveitado experiências estrangeiras, isso não implica um salto de etapas no processo evolutivo da autocomposição. É necessário que o progresso ocorra de forma natural e espontânea para a construção de uma identidade nacional sobre a matéria. Por isso, se exigirá ainda mais tempo para que a busca pela solução consensual dos conflitos habite a mente do brasileiro de forma preponderante.

Assim, na forma de desenvolvimento da institucionalização da conciliação e da mediação, existem dois pontos que devem ser observados. Primeiramente, o Poder Judiciário necessita estimular a autonomia privada das partes, incentivando $\mathrm{o}$ reconhecimento da efetividade das soluções tomadas pelas partes e a possibilidade de sua eficácia independentemente da homologação judicial. O segundo aspecto refere-se à criação de mecanismos que viabilizem o estímulo à autocomposição no âmbito do Poder Judiciário sem impedir a progressiva desjudicialização dos conflitos.

é o que eu chamo 'Institucionalização'. A questão é: como tecer ADR [alternative dispute resolution] no tecido de resolução de disputas para que as opções de ADR sejam sistematicamente consideradas em vários pontos ao longo da vida de uma disputa, em vez de colocar o ônus na parte que deseja usar ADR, o que muitas vezes será interpretado como sinal de fraqueza? Essa é a tarefa em que estamos atualmente engajados e esse será nosso principal desafio no futuro" (tradução nossa). No original: "The first period, I think, was about 1975 to 1982. I call it, 'Let a thousand flowers bloom.' [...] The second period, about 1982 to 1990 - and these dates are pretty impressionistic on my part - I call 'Cautions and caveats': Concerns about where we're heading, attempts to sort out the wheat from the chaff. [...] The third period, starting about 1990, is what I call 'Institutionalization'. The question there is: How do we weave ADR into the dispute resolution fabric so that ADR options are systematically considered at various points along the life of a dispute rather than putting the onus on the party who wants to use ADR, which will often be construed as a sign of weakness? That's the task we are currently engaged in and that will be our principal challenge in the future". (SANDER, Frank E. A. The Future of ADR: The Earl F. Nelson Memorial Lecture. Journal of Dispute Resolution, Columbia, n. 1, p. 3-10, 2000, p. 2-3). 
O Poder Judiciário precisa incentivar o desenvolvimento da autocomposição extrajudicial para que essa via seja progressivamente mais buscada pelos litigantes. É nisso que consiste basicamente a ideia tão propalada de desjudicialização dos litígios. Não se está a defender a saída integral e imediata do Judiciário da gestão consensual dos conflitos, longe disso.

A realidade brasileira impõe uma mudança gradual da cultura que passa necessariamente por uma fase inicial de valorização dos meios consensuais no âmbito judicial. A participação do Poder Judiciário é valorosa no momento atual do desenvolvimento, pois a sociedade reconhece nesse Poder Judiciário a legitimidade para a solução dos conflitos. Assim, a adoção dessas práticas pelo Judiciário soa para a população como uma validação dos métodos autocompositivos, os quais não precisam ser realizados necessariamente no domínio judicial.

O que o Judiciário não pode é criar mecanismos que atraiam mais conflitos para o âmbito judicial, instigando a judicialização de conflitos que antes não eram tratados judicialmente. É o caso, por exemplo, de algumas ações ligadas ao estímulo de sessões pré-processuais em Cejusc, que deveriam ser dirigidas às causas que eram submetidas ao Judiciário, mas que estão visando viabilizar uma homologação judicial simplificada de acordos extrajudiciais que já não eram levados à Justiça.

O conceito que se pretende construir é o pluralismo de meios, em contraste com o monopólio da solução de conflitos pelo Judiciário. A força atrativa que o Judiciário tradicionalmente exerce sobre os conflitos tem de ser minimizada. E para isso é necessário o estreitamente de vínculos com as vias extrajudiciais de solução de conflitos.

Destaca-se neste ponto a importância da aproximação do Poder Judiciário das câmaras privadas de mediação e de conciliação para ações colaborativas, inclusive, por meio da remessa de processos a elas para a realização das sessões de mediação. ${ }^{32}$ Dessas inter-relações entre as iniciativas judiciais e extrajudiciais, extraem-se

32 Enunciado n. 37 do Fonamec: "O juiz coordenador do CEJUSC poderá remeter as partes para conciliação e mediação privadas". 
experiências frutíferas para ambos os lados. A mediação privada ganha notoriedade mais rapidamente, e a mediação judicial aprimora sua qualidade e sua eficiência.

Nesse aspecto merece referência também as Câmaras Administrativas de mediação e conciliação previstas pelo art. 174 do CPC e pelo art. 32 da Lei de Mediação, com autorização para solução de conflitos entre avaliar a admissibilidade dos pedidos de resolução de conflitos entre órgãos e entidades administrativas e entre particulares e as pessoas jurídicas de direito público. Sendo a Administração Pública uma das maiores, senão a maior, litigante do país, o pleno funcionamento dessas câmaras deve ser estimulado para garantir outras formas de abordagem distintas da decisão adjudicada.

A inclusão de vias autocompositivas extrajudiciais para os conflitos com a Administração Pública é, certamente, um dos caminhos que merecem ser trilhados para que o Estado cumpra o dever de promover a solução consensual dos conflitos. Todavia, esse instituto ainda carece de amadurecimento e de melhor regulamentação para evitar sua utilização como forma de deturpar mecanismos legais que asseguram a isonomia de tratamento entre os cidadãos.".33

A coexistência das duas realidades é especialmente proveitosa para os mediadores, que ganham nichos de mercado com exigências diferenciadas. A demanda judicial é mais volumosa, embora menos rentável, mostrando-se muito importante para profissionais que ainda estão ganhando experiência e construindo uma reputação. No âmbito privado, ao contrário, a procura é mais restrita e segue uma lógica de mercado, remunerando melhor os profissionais mais qualificados. A mediação privada serve de estímulo e perspectiva para os mediadores, instigando um aperfeiçoamento permanente para galgar o progresso profissional. ${ }^{34}$

\footnotetext{
${ }^{33}$ Nesse sentido leciona Janaína Soares Noleto Castelo Branco: "É primordial para o sucesso das câmaras administrativas que o cumprimento das obrigações de qualquer espécie, inclusive as de pagar, ocorra em âmbito administrativo, e não na via judicial por meio de precatório requisitório de pagamento. A adoção desse entendimento muito estimulará a busca dos interessados por esse mecanismo alternativo de resolução de conflitos". (CASTELO BRANCO, Janaína Soares Noleto. Advocacia pública e solução consensual dos conflitos. Salvador: Juspodivm, 2018, p. 153).

${ }^{34} \mathrm{Na}$ opinião de Gabriela Assmar e Débora Pinho: "Há, portanto, inevitáveis interdependências entre os espaços judiciais e privados da mediação. Numa lógica sustentável, é importante que ambos existam e se alimentem mutuamente: a mediação judicial provendo os jovens mediadores de experiências e o mercado de mediação privada sinalizando a estes que vale a pena dar o seu melhor a cada mediação, para que se
} 


\section{CONSIDERAÇÕES FINAIS}

É possível afirmar, a título de conclusão, que a universalização do acesso ao Judiciário foi uma das mais importantes conquistas na realização da garantia constitucional do acesso à justiça. Por outro lado, foi possível constatar que a distorção em algumas concepções do acesso à justiça contribuiu para a ampliação da tendência para a judicialização do conflito.

No Brasil, onde predomina uma lógica de concentração de poder no Estado, construída ao longo de uma história marcada por regimes centralizadores, existe um aparente consenso de que a melhor resposta a um conflito deve advir do Judiciário, Poder Estatal ao qual compete a função de dizer o direito em última instância.

Observou-se que a posição tradicional e conservadora do Judiciário impede que mudanças estruturais no modo de se portar perante o conflito se realizem de forma rápida. Há um apego dos profissionais do direito à ritualística forense clássica, pautada na autoridade do conhecimento técnico-jurídico, na exaltação dos procedimentos, símbolos linguagem e na hierarquia de poder. A inserção dos meios consensuais no âmbito judicial, muitos dos quais subvertem quase que integralmente essa lógica, naturalmente causam receio.

Concluiu-se que a incorporação dos métodos consensuais à realidade judicial, com a criação de um sistema judicial multiportas no Brasil, não é algo que se possa implementar em curto espaço de tempo. A lei não tem o condão de alterar a realidade no nível necessário para viabilizar uma mudança tão profunda de postura na sociedade e nos profissionais da área jurídica.

Constatou-se também que a existência de uma relação de complementaridade entre meios heterocompositivos e autocompositivos. Nesse contexto, destaca-se a necessidade de maior desenvolvimento dos meios consensuais no âmbito judicial para

alcance o reconhecimento que laureará suas carreiras. A mediação decorrente da demanda pública é para muitos. A privada, para poucos. Assim funciona em todos os países". (ASSMAR, Gabriela; PINHO, Débora. Mediação privada: um mercado em formação no Brasil. In: ZANETI JR., Hermes; CABRAL, Trícia Navarro Xavier. Justiça multiportas: mediação, conciliação e arbitragem e outros meios de solução adequada para conflitos. Salvador: Juspodivm, 2017. p. 589-606, p. 595). 
permitir uma ampliação do leque de opções de meios de solução de conflitos, garantindo uma maior capacidade de adaptação do processo judicial às especificidades dos casos concretos, em virtude de suas formas e seus níveis de intervenção na gestão do conflito.

Se um dos benefícios da institucionalização judicial da mediação é a desjudicialização dos conflitos, como efeito natural do empoderamento dos cidadãos e do desenvolvimento da solução consensual assistida, é preciso definir para onde irão os conflitos que hoje são judicializados. O Judiciário precisa minimizar a força gravitacional que exerce sobre os conflitos. Essa transformação passa pelo fortalecimento de uma nova gama de atividades para os profissionais da área jurídica, entre as quais a incorporação da solução extrajudicial dos conflitos à realidade profissional dos advogados e ao estímulo às câmaras privadas de mediação.

\section{REFERÊNCIAS:}

AMARAL, Márcia Terezinha Gomes. $O$ direito de acesso à justiça e a mediação. Rio de Janeiro: Lumen Juris, 2009.

ASSMAR, Gabriela; PINHO, Débora. Mediação privada: um mercado em formação no Brasil. In: ZANETI JR., Hermes; CABRAL, Trícia Navarro Xavier. Justiça multiportas: mediação, conciliação e arbitragem e outros meios de solução adequada para conflitos. Salvador: Juspodivm, 2017. p. 589-606.

BARBOSA MOREIRA, José Carlos. O problema da divisão de trabalho entre juiz e partes: aspectos terminológicos. In: Temas de direito processual. São Paulo: Saraiva, 1989.

CAPPELLETTI, Mauro; GARTH, Bryant. Acesso à justiça. Tradução de Ellen Gracie Northfleet. Porto Alegre: Sergio Antonio Fabris, 1988.

CARVALHO, José Murilo de. A construção da ordem/teatro de sombras. 2. ed. Rio de Janeiro: Relume Dumara, 1996.

CASTELO BRANCO, Janaína Soares Noleto. Advocacia pública e solução consensual dos conflitos. Salvador: JusPodivm, 2018. 
CRESPO, Mariana Hernandez; SANDER, Frank. A dialogue between Professors Frank Sander and Mariana Hernandez Crespo: exploring the evolution of the multidoor courthouse (Part One). University of St. Thomas Law Journal, Saint Paul, MN, v. 5, n. 3, p. 665-674, 2008. Disponível em: http://papers.ssrn. com/sol3/papers.cfm?abstract_id=1265221.

DIAS, Jean Carlos; HOMCI, Arthur Laércio; MOUTA, José Henrique et al. Curso de processo civil: processo de conhecimento de acordo com o novo CPC. Rio de Janeiro: Lumen Juris, 2016.

GORETTI, Ricardo. Mediação e acesso à justiça. Salvador: Juspodivm, 2017.

LUCHIARI, Valeria Ferioli Lagrasta. Histórico dos métodos alternativos de solução de conflitos. In: GROSMAN, Cláudia Frankel; MANDELBAUM, Helena Gurfinkel (org.). Mediação no Judiciário: teoria na prática e prática na teoria. São Paulo: Primavera Editorial, 2011.

MANCUSO, Rodolfo de Camargo. Acesso à justiça: condicionantes legítimas e ilegítimas. São Paulo: Revista dos Tribunais, 2011.

MARTÍN, Nuria Belloso. A mediação: a melhor resposta ao conflito? In: SPENGLER, Fabiana Marion; LUCAS, Douglas Cesar (org.). Justiça restaurativa e mediação: políticas públicas no tratamento dos conflitos sociais. Ijuí: Unijuí, 2011. p. 317-355.

MEDEIROS, Isabela. Assistência jurídica gratuita: cidadania e emancipação. Rio de Janeiro: Lumen Juris, 2013.

PONTIFICA UNIVERSIDADE CATÓLICA DO RIO GRANDE DO SUL. Demandas judiciais e morosidade da Justiça Civil: Relatório final. Porto Alegre: CNJ, 2011.

PRATA, Ana. Tutela constitucional da autonomia privada. Coimbra: Almedina, 1982.

PRESTON, Brian. The Land and Environment Court of New South Wales: moving towards a multi-door courthouse. Australasian Dispute Resolution Journal, v. 19, n. 3, p. 144-155, Aug. 2008. Disponível em: http://www.bocsar.nsw.gov.au/lawlink/lec/ll_lec.nsf/vwFiles/Paper_15Nov07_P reston_LEC_Multi_door_Court.doc/\$file/Paper_15Nov07_Preston_LEC_Multi_ door_Court.doc. 
RAATZ, Igor. Autonomia privada e processo: liberdade, negócios jurídicos processuais e flexibilização procedimental. $2^{a}$ edição. Salvador: Juspodivm, 2019.

RABELO, Patrícia Freire de Paiva Carvalho; NUNES, Soraya Vieira. A mediação como forma de resolução de conflitos: uma análise crítica do CPC/15 à luz da Lei 13.140/2015. In: PEIXOTO, Renata Cortez Vieira; SOUSA, Rosalina Freitas Martins de; ANDRADE, Sabrina Dourado França (coord.). Temas relevantes de Direito Processual Civil: elas escrevem. Recife: Armador, 2016. p. 31-44.

RODRIGUES JÚNIOR, Walsir Edson. A prática da mediação e o acesso à justiça. Belo Horizonte: Del Rey, 2006.

ROCHA, José de Albuquerque. Instituições arbitrais. In: SALES, Lília Maia de Morais (org.). Estudos sobre mediação e arbitragem. Rio de Janeiro: ABC Editora, 2003.

SADEK, Maria Tereza. Judiciário: mudança e reformas. Estudos Avançados, São Paulo, v. 18, n. 51, p. 79-101, maio/ago. 2004.

SALES, Lília Maia de Morais; CALOU, Marília Bitencourt C. A cultura da mediação e a contraposição de paradigmas: uma análise da cooperação e autonomia na resolução de conflitos. Revista Eletrônica Direito e Política, Itajaí, v. 12, n. 3, p. 1290-1313, 3. quadr. 2017.

SANDER, Frank E. A. The Future of ADR: The Earl F. Nelson Memorial Lecture. Journal of Dispute Resolution, Columbia, n. 1, p. 3-10, 2000.

SANTOS, Boaventura de Sousa. Pela mão de Alice: o social e o político na pós modernidade. 9. ed. São Paulo: Cortez, 2003.

SCHWARTZ, Stuart B. Burocracia e sociedade no Brasil Colonial: A Suprema Corte da Bahia e seus juízes. 1601-1751. São Paulo: Perspectiva, 1979.

SILVA, Érica Barbosa e. Conciliação judicial. Brasília, DF: Gazeta Jurídica, 2013.

TARTUCE, Fernanda. Mediação nos conflitos civis. 62. ed. São Paulo: Método, 2020.

WAMBIER, Luiz Rodrigues. Anotações sobre o princípio do devido processo legal. Revista do Tribunais. Ano 78-Ago. Vol. 647. São Paulo: Revista dos Tribunais, 1989.

WATANABE, Kazuo. Política pública do Poder Judiciário nacional para tratamento adequado dos conflitos de interesses. In: PELUSO, Antonio Cezar; RICHA, 
Revista Eletrônica de Direito Processual - REDP.

Rio de Janeiro. Ano 16. Volume 23. Número 1. Janeiro a Abril de 2022

Periódico Quadrimestral da Pós-Graduação Stricto Sensu em Direito Processual da UERJ

Patrono: José Carlos Barbosa Moreira (in mem.). ISSN 1982-7636. pp. 1021-1052

www.redp.uerj.br

Morgana de Almeida (coord.). Conciliação e mediação: estruturação da política judiciária nacional. Rio de Janeiro: Forense, 2011. 